\title{
PENINGKATAN KEMAMPUAN MENULIS TEKS EKSPLANASI KOMPLEK MELALUI MODEL STAD PADA SISWA SMA
}

\author{
Moch. Saleh \\ SMA Negeri 1 Gading Kecamatan Gading Kabupaten Probolinggo

\begin{abstract}
Abstrak: Banyak kegiatan yang berhubungan erat dengan keterampilan menulis, misalnya membuat ikhtisar, membuat catatan, menulis notulen, menulis berbagai macam surat, menulis rancangan kegiatan, sampai pada kemampuan menulis karya ilmiah. Tulisan teks eksplanasi komplek merupakan tulisan yang menceritakan suatu peristiwa yang tersusun secara teratur. Sementara itu Student Teams Achievement Division (STAD) merupakan salah satu metode yang sangat mengutamakan kerjasama yang baik di dalam tim. Kemampuan menulis teks ekplanasi komplek siswa kela XI MIA - 2 SMA Negeri I Gading pada siklus I sebanyak (52\%) tuntas belajar dan $(48 \%)$ siswa belum tuntas belajar. Kemudian setelah dilakukan tindakan pada siklus II diperoleh hasil belajar sebanyak (95\%) tuntas belajar
\end{abstract} \\ dan $(5 \%)$ belum tuntas belajar
}

Kata kunci: kemampuan, menulis, teks eksplanasi komplek, STAD.

Dalam pengajaran atau proses belajar mengajar guru memegang peran sebagai sutradara sekaligus aktor. Artinya, guru memegang tugas dan tanggung jawab merencanakan dan melaksanakan pengajaran di sekolah. Oleh karena itu apabila siswa kurang menunjukkan keterampilan dalam suatu mata pelajaran, maka bisa dikatakan kurangnya keberhasilan guru dalam Kegiatan Bejar Mengajar ( KBM ).

Salah satu yang bisa digunakan untuk meningkatkan prestasi mata pelajaran Bahasa Indonesia menulis teks ekplanasi komplek yang dikembangkan guru perlu memperhatikan kualitas pembelajaran yang disebabkan oleh beberapa faktor, yaitu : (1) siswa kurang mengidentifikasi ide dan penghayatan sehingga kemampuan menulis teks ekplanasi siswa rendah, (2) siswa kesulitan dalam menuangkan idenya ke dalam bentuk tulisan yang utuh, (3) siswa tidak terbiasa menceritakan pengalaman atau suatu peristiwa melalui tulisan teks hinggga kurang terstuktur (4) kurangnya kemampuan siswa dalam menghayati pada topik (5) kurangnya kemampuan mengembangkan imajenasi (6) guru kesulitan dalam membangkitkan minat belajar siswa (7) guru kesulitan menentukan metode atau cara yang tepat untuk menyampaikan materi. Oleh karenanya perlu adanya pembaharuan dalam pembelajaran di kelas sehingga dapat menjadikan motifasi dalam penulisan suatu karya misal menggunakan media gambar. Dalam pengembangan pembelajaran di kelas seluruh siswa diharapkan adanya kerterlibatan aktif dalam kegiatan.

Teks merupakan tulisan yang menceritakan suatu peristiwa yang tersusun secara teratur sehingga menimbulkan pengertian-pengertian yang dapat merefleksi interpretasi penulisnya. Keterampilan menulis merupakan keterampilan berbahasa yang sangat penting bagi siswa. Keterampilan ini sangat besar artinya bagi siswa selama ia mengikuti kegiatan pendidikan di bangku sekolah. Banyak kegiatan yang berhubungan erat dengan keterampilan menulis yang harus diselesaikan siswa, yaitu membuat ikhtisar, membuat catatan, menulis notulen, 
menulis berbagai macam surat, menulis proposal penelitian, menulis rancangan kegiatan, sampai pada kemampuan menulis karya ilmiah. Akhaidah (2002:2) mengungkapkan bahwa menulis berarti mengorganisasikan gagasan secara sistematis serta mengungkapkannya secara tersurat. Mengacu pada hakikat tulisan di atas, keterampilan menulis siswa dapat menceritakan suatu peristiwa atau kejadian dalam kehidupan sehari hari. Pengajaran menulis ditujukan agar siswa mampu memahami dan dapat mengkomunikasikan ide atau gagasan dalam bentuk tulisan. Hal ini penting karena kemampuan menulis seseorang merupakan gambaran dari penguasaan bahasa yang digunakan. Secara umum siswa memang mampu menulis namun mereka kurang memiliki ekspresi gagasan yang berkesinambungan dan belum mempunyai urutan logis dengan menggunakan kosakata atau tata bahasa atau kaidah bahasa yang digunakan sehingga tidak dapat menceritakan peristiwa yang diekspresikan secara jelas.

Menulis dapat melahirkan pikiran atau perasaan (seperti mengarang, membuat surat) dengan tulisan. Menulis dapat pula diartikan sebagai pengekspresian sesuatu dengan menggunakan bahasa tulis. Sesuatu dalam hal ini bisa berarti pemikiran, perasaan, dan pengalaman, baik pemikiran, perasaan, dan pengalaman sendiri maupun pemikiran, perasaan, dan pengalaman orang lain. Melalui media gambar pembelajaran menulis teks ekplanasi komplek akan berlangsung lebih menyenangkan, dan hasil belajar siswa optimal.

Menurut pengamatan penulis dalam pelaksanaan pembelajaran di kelas khususnya di kelas XI MIA - 2 SMA Negeri I Gading masih menggunakan model pembelajaran ekposisi yakni model pembelajaran yang berpusat pada guru, sedangkan keberadaan siswa sebagai anak yang aktif dan kreatif masih kurang diperhatikan. Salah satu penyebab pembelajaran tersebut cenderung anak menjadi pasif, guru belum mampu mengembangkan karakteristik anak, menulis teks ekplanasi komplek merupakan materi pembelajaran yang kurang dikuasai siswa. Suasana pembelajaran tidak menggairahkan, siswa malas dalam mengikuti pembelajaran, dan kemampuan menulis teks ekplanasi komkplek. Kondisi tersebut tidak semata-mata disebabkan oleh sulitnya materi pembelajaran menulis teks atau rendahnya kemampuan siswa. Dari hasil studi lapangan, pembelajaran menulis teks ekplanasi komplek yang tidak kondusif tersebut disebabkan oleh beberapa hal: (a) guru kurang menyukai pembelajaran pengetahuan bahasa, terutama menulis teks, (b) guru kurang atau bahkan tidak berpengalaman bergaul dengan karya sastra, terutama menulis teks, dan (c) metode pembelajaran yang dipilih dan digunakan oleh guru tidak atau kurang tepat. Kondisi semacam ini akan berdampak pada nilai keterampilan menulis teks yang tergolong masih rendah. Hal ini dapat dilihat dari nilai rata- rata kelas untuk mata pelajaran Bahasa Indonesia pada materi menulis teks ekplanasi komplek. Oleh karena itu permasalahan ini perlu untuk diteliti dan dicari penyelesaiannya.

Berdasarkan uraian diatas, perlu untuk melakukan penelitian dengan menggunakan tindakan kelas ( PTK ) guna mencari solusi dan permasalahan tersebut. Penelitian mengembangkan perangkat pembelajaran yang mencirikan model pembelajaran kooperatif sebagai salah satu alternatif untuk mengatasi pembelajaran Bahasa Indonesia. Model pembelajaran kooperatif atau Cooperatve learning, pembelajaran kooperatif mencakup suatu kelompok kecil yang bekerja sebagai sebuah tim untuk menyelesaikan sebuah masalah, menyelesaikan suatu tugas, atau mengerjakan sesuatu untuk mencapai tujuan bersama kelompoknya. 
Oleh sebab itu, diperlukan adanya kreatifitas guru agar memiliki keahlian untuk memilih dan menggunakan strategi pembelajaran yang sesuai agar pembelajaran bersifat menyenangkan dan siswa mampu bersikap aktif sehingga keberhasilan dalam belajar dapat tercapai secara optimal. Menurut Mulyasa (dalamYiyin Anggarini, 2010 : 2), guru perlu memperhatikan beberapa hal untuk mendukung siswa mencapai keberhasilan belajar, yaitu (1) mengurangi metode ceramah, (2) bahan harus dimodifikasi dan diperkaya, (3) menggunakan prosedur yang bervariasi, (4) menciptakan situasi belajar yang dapat mengembangkan kemampuan anak untuk bekerjasama, (5) melibatkan siswa dalam berbagai kegiatan.

Berdasarkan uraian diatas peneliti dapat menyimpulkan bahwa model pembelajaran adalah suatu kegiatan atau aktivitas yang dilakukan seseorang untuk mengorganisasi, mengatur dan menyampaikan bahan pelajaran kepada murid agar dapat menerima, menanggapi, menguasai dan mengembangkan bahan-bahan pelajaran sehingga terjadi proses pelajaran.

Pembelajaran Kooperatif adalah bentuk pembelajaran yang berdasarkan faham konstruktivis. Pembelajaran kooperatif merupakan strategi belajar dengan sejumlah siswa sebagai anggota kelompok kecil yang tingkat kemampuannya berbeda. Dalam menyelesaikan tugas kelompoknya, setiap siswa anggota kelompok harus saling bekerja sama dan saling membantu untuk memahami materi pelajaran. Model STAD merupakan salah satu metode pengajaran tipe pembelajaran kooperatif yang menekankan pada adanya aktifitas dan interaksi diantara siswa untuk saling memotivasi dan saling membantu dalam menguasai materi pelajaran guna mencapai prestasi yang maksimal.

Menurut Slavin (2005: 3-4)dalam hal ini penerapan pembelajaran kooperatif dilaksanakan, atas dasar teori siswa akan lebih mudah menemukan dan memahami konsep-konsep yang sulit apabila mereka dapat saling mendiskusikan konsep-konsep itu dengan temannya.

Beberapa ciri dari pembelajaran kooperatif adalah ; (a) setiap anggota memiliki peran, (b) terjadi hubungan interaksi langsung di antara siswa, (c) setiap anggota kelompok bertanggung jawab atas belajarnya juga teman - teman sekelompoknya, (d) guru membantu mengembangkan keterampilan keterampilan interpersonal kelompok, (e) guru hanya akan berinteraksi dengan kelompok saat diperlukan.

Tujuan utama dari pengajaran ini adalah guru menyajikan materi pelajaran sesuai dengan yang direncanakan. Setiap awal dalam pembelajaran kooperatif tipe STAD selalu dimulai dengan penyajian kelas,mencakup pembukaan, pengembangan dan latihan terbimbing dari keseluruhan pelajaran dengan penekanan dalam penyajian materi pelajaran.

\section{METODE}

Bentuk PTK yang dilakukan dalam penelitian ini kolaboratif. Dalam pelaksanaan penelitian penulis sebagai guru mata pelajaran Bahasa Indonesia bekerjasama dengan pihak lain sesama guru mata pelajaran Bahasa Indonesia. Sehingga selama kegiatan penelitian berlangsung penulis dibantu oleh observer yang berfungsi sebagai pengamat. Hal ini dimaksudkan supaya peneliti lain dapat memberikan masukan atau informasi data yang lebih lengkap apabila peneliti kurang cermat dalam mengumpulkan data. Desain penelitian yang digunakan 
mengacu pada model Kemmis dan M.C. Taggart ( dalam Arikunto 2009: 16) yang terdiri dari 4 komponen yaitu: perencanaan, tindakan, observasi, dan refleksi.

Subjek Penelitian Penelitian Tindakan Kelas ini dilaksanakan di Kelas XI MIA-2 SMA Negeri I Gading Kec. Gading Kab. Probolinggo pada tanggal 04 Februari 2015 pada mata pelajaran Bahasa Indonesia dengan Jumlah siswa 23 yang terdiri atas 15 siswa Putra dan 8 siswa Putri. Sebagai salah satu sekolah yang berada di Pinggiran, komunikasi keseharian siswa di sekolah masih sedikit yang menggunakan Bahasa Indonesia. Tingkat pendidikan orang tua murid juga mempengaruhi kemampuan siswa yang mayoritas relatif rendah terutama dalam berbahasa Indonesia. Kebiasaan menggunakan bahasa ibu ( Bahasa Daerah), dalam hal ini bahasa Madura, menyebabkan mereka sedikit kesulitan untuk berbahasa Indonesia dengan baik dan benar.

Pada dasarnya Penelitian Tindakan Kelas (PTK) memiliki karakteristik yaitu: (1) bersifat situasional, artinya mencoba mendiagnosis masalah dalam konteks tertentu, dan berupaya menyelesaikannya dalam konteks itu; (2) adanya kolaborasi-partisipatoris; (3) self-evaluative, yaitu modifikasi-modifikasi yang dilakukan secara kontinyu - dievaluasi dalam situasi yang terus berjalan secara siklus, dengan tujuan adanya peningkatan dalam praktek nyatanya.Tahap Penelitian Tindakan Kelas secara umum mencakup empat langkah.

Teknik observasi digunakan untuk melihat dan mengamati kejadian yang terjadi di lapangan secara langsung. Pernyataan tersebut sesuai dengan pendapat Riduwan (2004:104) menyatakan teknik observasi merupakan teknik pengumpulan data, di mana peneliti melakukan pengamatan secara langsung keobjek penelitian untuk melihat dari dekat kegiatan yang dilakukan. Berdasarkan pendapat di atas, maka menurut peneliti teknik observasi cara yang digunakan untuk mengumpulkan data, di mana peneliti melakukan pengamatan secara langsung keobjek penelitian. Sedangkan Arikunto (2009:19) mengungkapkan tahap observasi merupakan kegiatan pengamatan yang dilaksanakan oleh pengamat.

Kegiatan observasi dilaksanakan secara kolaboratif untuk mengamati keterampilan guru, serta hasil belajar siswa pada pembelajaran Bahasa Indonesia menerapkan mudel STAD. Observasi terkait dengan kegiatan evaluasi proses dan hasil belajar dapat dilakukan secara formal yaitu observasi dengan menggunakan instrumen yang sengaja dirancang untuk mengamati unjuk kerja dan kemajuan belajar peserta didik, maupun observasi informal yang dapat dilakukan oleh peneliti tanpa menggunakan instrumen. Pada penelitian ini peneliti melakukan observasi sesuai dengan pendapat Hadi (dalam Sugiyono 2010: 145) mengobservasi suatu proses yang kompleks yang tersusun dari berbagai proses pengamatan dan ingatan. Pernyataan tersebut sesuai dengan pendapat Wiraatmadja (2006:125) menyatakan catatan lapangan merupakan sumber informasi yang sangat penting yang dibuat oleh peneliti atau mitra peneliti yang melakukan pengamatan atau observasi. Berdasarkan pendapat di atas, maka menurut peneliti catatan lapangan yang digunakan peneliti berisi sumbe rinformasi yang sangat penting yang dibuat oleh peneliti yang sedang melakukan observasi.

Refleksi merupakan tindakan mengevaluasi uji coba yang telah dilakukan yaitu tinjauan kembali dengan memperbaiki kekurangan-kekurangan yang ada dalam proses pembelajaran. Pada tahap ini penulis telah melakukan sesuai dengan 
pendapat Arikunto (2009:19- 20 ) bahwa "refleksi kegiatan digunakan untuk mengemukakan kembali apa yang sudah dilakukan". Setelah mengkaji keterampilan guru, aktivitas siswa dan hasil belajar siswa maka peneliti melakukan perbaikan pada siklus selanjutnya. Kegiatan refleksi itu terdiri atas 4 komponen kegiatan, yaitu: analisis, pemaknaan, penjelasan data hasil analisa dan penyimpulan apakah masalah itu teratasi atau tidak. Peneliti akan melihat apakah indikator kinerja yang telah ditetapkan sebelumnya telah tercapai atau belum. Bila belum tercapai maka peneliti melanjutkan siklus berikut sampai mencapai indikator kinerja. Namun bila hasil data keterampilan guru, dan hasil belajar mencapai indikator keberhasilan yang telah ditentukan, maka penelitian dihentikan.

\section{HASIL DAN PEMBAHASAN}

Hasil dariobservasi model pembelajaran STAD telah dilaksanakan dengan baik dan sesuai dengan langkah-langkah pada rencana pelaksanaan pembelajaran. aktivitas guru pada pelaksanaan tindakan pada siklus I yaitu guru telah melaksanakan pembelajaran dengan baik, diantaranya guru telah membuka pelajaran dengan baik, dengan memberikan apersepsi terlebih dahulu, selanjutnya guru menyiapkan media pembelajaran, menunjukan kepada siswa serta memberikan penjelasan materi tentang menulis teks Ekplanasi Komplek. Kemudian guru meminta kepada siswa untuk mempelajari sendiri materi yang telah diberikan dengan membaca teks bacaan yang telah diberikan oleh guru. Kegiatan selanjutnya yaitu guru membentuk kelompok sebanyak 4 kelompok dalam 1 kelas. Siswa melakukan diskusi kelompok dan dibimbing oleh guru, diskusi kelompok berjalan dengan lancar karena guru sudah dapat mengelola kelas dengan baik.

Langkah selanjutnya adalah langkah pokok yaitu guru mengajak siswa untuk mengamati gambar sebelum diajak berimajenasi guru menerangkan terlebih dahulu cara merangkai kata demi kata. Siswa terlihat memperhatikan saat guru menerangkan cara merangkai kata. Setelah selesai menerangkan siswa mulai merangkai kata. Siswa terlihat lebih aktif menyampaikan pendapat dan siswa lebih mudah memahami materi melalui pengamatan seperti ini. Kemudian langkah terakhir yang dilakukan guru yaitu melakukan refleksi, menyimpulkan materi yang telah diajarakan, hal ini bertujuan agar siswa mempunyai kemantapan terhadap materi yang telah diajarakan. Guru yang mengajar dengan menggunakan strategi pembelajaran yang sesuai akan dapat menimbulkan minat belajar siswa, sebaliknya guru yang tidak menggunakan strategi pembelajaran yang tidak sesuai tidak akan dapat menimbulkan minat belajar siswa. Hingga dapat dilihat dari presentase aktivitas guru yang dicapai dengan rata-rata skor yang diperoleh pada siklus I ini yaitu sebesar 73\%. Penerepan langkah-langkah model pembelajaran STAD pada siklus II sesuai dengan perencanaan yang telah diterapkan seperti pada siklus I. Berdasarkan observasi pada siklus II telah dapat dilaksanakan secara optimal pula. Hal ini terbukti dari hasil presentase aktivitas guru dengan rata-rata skor yang diperoleh pada siklus II ini yaitu sebesar $95 \%$. Kenaikan presentase aktivitas guru ini menandakan bahwa guru sudah menguasai dan dapat menerapkan langkah-langkah model pembelajaran STAD dengan baik.

Pada saat sebelum dilakukan kegiatan pembelajaran menggunakan model STAD hasil belajar siswa dapat dikatakan rendah karena tingkat keberhasilan 
siswa hanya mencapai 52\% yaitu dari 23 siswa hanya 12 siswa tuntas belajar dan rata-rata hasil akhir di kelas tersebut hanya 68 . Diperoleh hasil penelitian melalui tes pada siklus I nilai akhir belajar siswa menunjukkan adanya peningkatan, yaitu presentase Rata-rata ketuntasan siswa mencapai $69 \%$ yang berarti naik $13 \%$. Secara umum hal tersebut dapat dikatakan belum tuntas karena belum mencapai 75\% di kelasnya. Oleh karena itu, hasil perbaikan siklus II menunjukkan yaitu rata-rata mencapai $83 \%$ siswa yang sudah tuntas belajar. Secara umum hal tersebut dapat dikatakan sudah tuntas karena pencapaian diatas $75 \%$ tuntas belajar di kelas. Hasil ini menunjukkan bahwa model pembelajaran STAD dapat digunakan untuk meningkatkan hasil belajar Bahasa Indonesia menulis teks Ekplonasi Komplek.

\section{KESIMPULAN}

Hasil penelitian pembelajaran Bahasa Indonesia Menulis teks Ekplonasi Komplek melalui model pembelajaran STAD pada siswa kelas XI MIA - 2 di SMA Negeri I Gading Kematan Gading Kabupaten Probolinggo dan pembahasan yang disajikan pada bagian pembahasan dapat disimpulkan sebagai berikut: (1) Penerapan model STAD dalam pembelajaran Bahasa Indonesia Menulis teks Ekplonasi Komplek telah dilaksanakan dengan baik dan sesuai dengan langkahlangkah yang ada. Hal ini terbukti dari hasil aktivitas guru dalam mengajar yaitu pada siklus I rata-rata presentasi mencapai $73 \%$. Sedangkan pada siklus II aktivitas guru mencapai rata-rata 95\%. (2) Hasil belajar Bahasa Indonesia Menulis teks Ekplonasi Komplek teks Ekplonasi Komplek melalui model pembelajaran STAD pada siswa kelas XI MIA - 2 di SMA Negeri I Gading Kematan Gading Kabupaten Probolinggo dapat meningkat hal ini ditunjukan dengan peningkatan rata-rata hasil belajar siswa dan presentase ketuntasan yang dicapai. Rata-rata nilai akhir yang di dapat siswa pada siklus I mencapai $69 \%$, sedangkan pada siklus II rata-rata mencapai $78 \%$ Sedangkan rata-rata presentase ketuntasan yang dicapai pada siklus I mencapai 59\%, pada siklus II rata-rata presentasi mencapai $85 \%$.

\section{SARAN}

Simpulan dari pembelajaran Bahasa Indonesia Menulis teks Ekplonasi Komplek teks Ekplonasi Komplek melalui model pembelajaran STAD pada siswa kelas XI MIA - 2 di SMA Negeri I Gading Kematan Gading Kabupaten Probolinggo, maka peneliti memberikan saran yaitu (1) Bagi guru, dapat menerapkan model pembelajaran STAD sebagai salah satu solusi untuk meningkatkan kualitas pembelajaran Bahasa Indonesia menulis teks Ekplonasi Komplek meliputi keterampilan guru dalam mengajar dan hasil belajar siswa. (2) Bagi siswa, lebih bersungguh-sungguh dalam mengikuti proses pembelajaran khususnya pada mata pelajaran Bahasa Indonesia menulis teks Ekplonasi Komplek dengan menggunakan media gambar model pembelajaran STAD (Student Teams Achievement Division). (3) Bagi sekolah, dapat digunakan sebagai salah satu masukan dalam menggunakan model pembelajaran khususnya pada mata pelajaran Bahasa Indonesia. (4) Bagi peneliti lanjutan, semoga hasil penelitian ini dapat digunakan sebagai informasi untuk mengadakan penelitianpenelitian selanjutnya dengan menggunakan model dan strategi penelitian yang lebih kompleks sesuai dengan karakteristik siswa dan materi pelajaran. 


\section{DAFTAR RUJUKAN}

Arikunto, Suharsimi. 2009. Penelitian Tindakan Kelas. Jakarta: PT. Bumi Aksara.

Slavin, Robert E. 2005 Cooperative Learning Raecech. Bandung : Nusa Media

Kemmis, S dan Mc. Taggart, R 1998. The Action Research Planner-Victoria Dearcin University.

Kuntjojo dkk ; 2011. Modul Model-model Pembelajaran. Modul disajikan dalam Pendidikan dan Latihan Guru Profesional PSG Rayon Universitas Nusantara PGRI Kediri, Kediri, 2011

Riduwan. 2004. Metode Riset. Jakarta: Rineka Cipta.

Sugiyono. 2010. Metode Penelitian Kuantitatif Kualitatif dan $R \&$ D. Bandung: Alfabeta.

Wiraatmadja, Rochiati. 2006. Metode Penelitian Tindakan Kelas. Bandung: Rosdakarya. 